\title{
Logam Berat Anthropogenik Pb dan Cu pada Lapisan Sedimen Permukaan dan Dasar Muara Sungai di Kota Semarang, Jawa Tengah Indonesia
}

\author{
Chrisna Adhi Suryono*, Ibnu Pratikto dan Ajeng Rusmaharani \\ Departemen IImu Kelautan, Fakultas Perikanan dan IImu Kelautan, Universitas Diponegoro \\ Jl. Prof Soedarto, SH. Kampus UNDIP Tembalang Semarang 50275 \\ Email: chrisna_as@yahoo.com
}

\begin{abstract}
Abstrack
Anthropogenic Heavy Metal Pb and Cu in the Surface and Bed Sediments of the River Down Stream of Semarang Central Java Indonesia

Semarang coastal areas as specially on river down stream have been develop to industrial, dumpping areas and human settlement. Its will be caused increasing sedimentation and anthropogenic heavy metals accumulation in sediments. In order to assess $\mathrm{Pb}$, and $\mathrm{Cu}$ on diferent layers of sediments on three down stream rivers on Semarang, samples of surface and bed sediment were collected for analyzed by ICPMS. The result showed that the heavy metal of Pb on bed layer was higher than Pb on surface sediment, on the other hand Cu on surface sediment was higher than Cu on bed sediments. Unfraternally the heavy metal concentration on surface and beds sediments they do not correlation with totals organic carbon and combination silt and clay in sediment on three down stream rivers on Semarang.
\end{abstract}

Keywords: Heavy metals Anthropogenic; sediment; totals organic carbon; silt; clay

\begin{abstract}
Abstrak
Wilayah pesisir Semarang terutama di daerah muara sungai telah berkembang menjadi kawasan industri, penimbunan dan hunian. Hal tersebut menyebabkan peningkatan sedimentasi dan akumulasi antropogenik logam berat dalam sedimen. Untuk mengetahui logam berat $\mathrm{Pb}$ dan Cu dalam permukaan dan dasar sedimen di tiga muara sungai Semarang. Maka sampel pada permukaan dan dasar sedimen diambil dan dianalisa dengan ICPMS. Hasil pengukuran menunjukan bahwa konsentrasi logam $\mathrm{Pb}$ pada lapisan dasar lebih tinggi dari pada lapisan permukaan sedimen, sebaliknya konsentrasi logam Cu pada lapisan permukaan lebih tinggi dari pada lapisan dasar sedimen. Namun keseluruhan antropogenik logam berat Pb dan Cu pada lapisan permukaan maupun bawah sedimen tidak ada korelasinya dengan kandungan total bahan organik karbon dan kombinasi antara silt dan clay dalam sedimen di ketiga mura sungai di Semarang.
\end{abstract}

Kata Kunci: Logam berat antropogenik; sedimen; total organic carbon; silt; clay

\section{PENDAHULUAN}

Pesisir Kota Semarang terdapat beberapa muara sungai yang mengalir ke daerah tersebut dengan membawa sedimen dari hulu seperti Sungai Plumbon, Beringin, Banjir Kanal Barat, Semarang, Banjir Kanal Timur, Tenggang, Babon dan Sringin. Sungai sungai tersebut mengalir dari hulu dengan melewati beberapa daerah dengan berbagai pemanfaatan seperti pertanian, pemukiman, maupun daerah industri. Maka dengan demkian sedimen yang terbawa oleh aliran air dan diendapkan di muara sungai diduga juga mengendapkan beberapa potulan seperti logam berat. Sedimen di beberata daerah pesisir Kota Semarang seperti dearah Tugu telah terkontaminasi logam berat seperti $\mathrm{Cr}, \mathrm{Pb}$ dan $\mathrm{Cu}$ (Suryono, 2016). Logam berat Pb, $\mathrm{Cr}$ 
dan $\mathrm{Cd}$ juga ditemukan dalam perairan pelabuhan Semarang yang diduga akan meningkatkan konsentrasi logam berat dalam sedimen (Suryono dan Djunaedi, 2017). Secara alami muara sungai atau daerah estuaria merupakan daerah pengendapan bagi ion-ion yang terlarut di daerah percampuran antara air tawar dan laut (Hunter, 1983). Terlebih tiga sungai (Plumbon, Banjir Kanal Barat dan Sringin) yang menjadi daerah penelitian telah banyak mengalami perubahan dalam pemanfaatan sepanjang daerah aliran sungai sampai muara. Tingginya kandungan silt dan clay pada sedimen di daerah muara biasanya terbawa saat banjir dengan membawa berbagai polutan seperti logam berat, hal tersebut dapat dijadikan petunjuk adanya peningkatan atau penurunan tingkat pencemaran (Daessle et al., 2009). Peningkatan logam berat dalam sedimen disebabkan oleh pengendapan logam berat yang terlarut dan partikel maupun ikantanikatan yang mengalir melalui saluran pembuangan (Galanopoulou et al., 2009).

Sedimen dapat menjadi perangkap polutan dan telah terbukti sangat efisien sebagai cara untuk mengidentifikasi dampak lingkungan (Strauch et al., 2008). Sedimen juga memiliki kemampuan dalam menyimpan polutan yang anti air (hydrophobic pollutants) atau bahan biomarker (Viguri et al., 2002). Sedimen ternyata sangat bermanfaat dalam pengukuran tingkat kontaminasi dari ekosistim perairan, bukan hanya kemampuannya dalam mengakumulasi logam dan bahan organik namun juga mampu membawa sumber kontaminan ke dalam perairan (Mariani dan Pompeo 2008). Materi kimia biasanya lepas dari sedimen ke perairan disebabkan oleh kondisi lingkungan dan kondisi fisika-kimia seperti $(\mathrm{pH}$, redox potensial dan aktifitas mikrobiologis) hal tersebut dapat menkontaminasi perairan dan sistim lingkungan lainnya yang berakibat penurunan kwalitas perairan (Froehner dan Martins 2008). Namun kemampuan sedimen dalam menyerap dan melepaskan material yang anti air (hydrophobic compounds) tergantung pada kandungan bahan organik karbon dalam sedimen (Rutemberg dan Goni 1997). Karena sedimen mudah menyimpan polutan dan hal tersebut terkait juga dengan keberadaan bahan organik karbon dan kandungan silt dan clay dalam sedimen. Maka tujuan dari penelitian ini adalah untuk mengetahui polutan logam berat dalam sedimen dan hubungannya dengan keberadaan bahan organik karbon maupun silt dan clay sedimen di tiga muara sungai Semarang.

\section{MATERI DAN METODE}

Materi yang digunakan dalam penelitian ini adalah sedimen yang diambil dari tiga muara sungai (Plumbon, Banjir Kanal Barat dan Sringin) yang mengalir di pesisir Kota Semarang. Sedimen diambil dengan core sampler pada kedalaman $0 \mathrm{~cm}$ sampai $100 \mathrm{~cm}$, sedimen di bagian atas dua bagian. Bagian permukaan mulai kedalaman $0 \mathrm{~cm}$ sampai $20 \mathrm{~cm}$ sedangkan dasar mulai dari kedalam $80 \mathrm{~cm}$ sampai $100 \mathrm{~cm}$. Selanjutnya sedimen dianalisa kandungan logam berat, total organik karbon (TOC) dan jenis sedimen. Analisa total organik karbon menggunakan metode pengabuan (Metcalf dan Eddy, 1991) dan analisa jenis sedimen menggunakan metode pengayakan dan pemipetan (Daessle et al. 2002). Sedangkan analisa logam berat pada sampel sedimen mengacu (Liv et al., 2013).

Sampel sedimen didistruksi dengan HNO3 (Super pure, Merck, Germany) dalam tabung Teflon. Konsenrasi logam berat sedimen diukur dengan Inductively Coupled Plasma Mass Spectrometry (ICP-MS) (Elan DRC II, Perkin Elmer Company, USA). Untuk mengetahui korelasi antara logam berat $\mathrm{Pb}$ dan Cu dalam sedimen permukaan maupun dasar terhadap total bahan organik karbon maupun (silt + clay) baik permukaan maupun dasar digunakan regresi berganda MINITAB 13.3

\section{HASIL DAN PEMBAHASAN}

Hasil penelitian menunjukan bahwa logam berat $\mathrm{Pb}$ dan $\mathrm{Cu}$ telah terakumulasi pada sedimen bagian permukaan $(0-20 \mathrm{~cm})$ dan dasar $(80-100 \mathrm{~cm})$ di tiga muara sungai Plumbon, Banjir Kanal Barat dan Sringin dalam konsentrasi yang relatip tinggi. Hasil tersebut dapat dilihat dalam Gambar 2. 
Gambar 2 menunjukan bahwa konsentrsi $\mathrm{Pb}$ yang terdapat dalam sedimen permukaan dan dasar lebih tinggi dibandingkan dengan konsentrsi $\mathrm{Cu}$ di semua muara sungai menunjukan perbedaan yang nyata $(p<0,05)$. Sedangkan perbandingan antara $\mathrm{Pb}$ permukaan dan dasar pada semua muara sungai tdak ada perbedaan yang sangat nyata $(0,05<p)$. Demikian juga halnya yang terlihat pada Cu permukaan dan dasar menunjukan tdak ada perbedaan yang sangat nyata $(0,05<\mathrm{p})$. Ketidak aturan konsentrasi logam berat $\mathrm{Pb}$ dan Cu dari permukaan ke bagian yang lebih dalam (dasar) hal tersebut sangat memungkinkan. Karena keberadaan logam

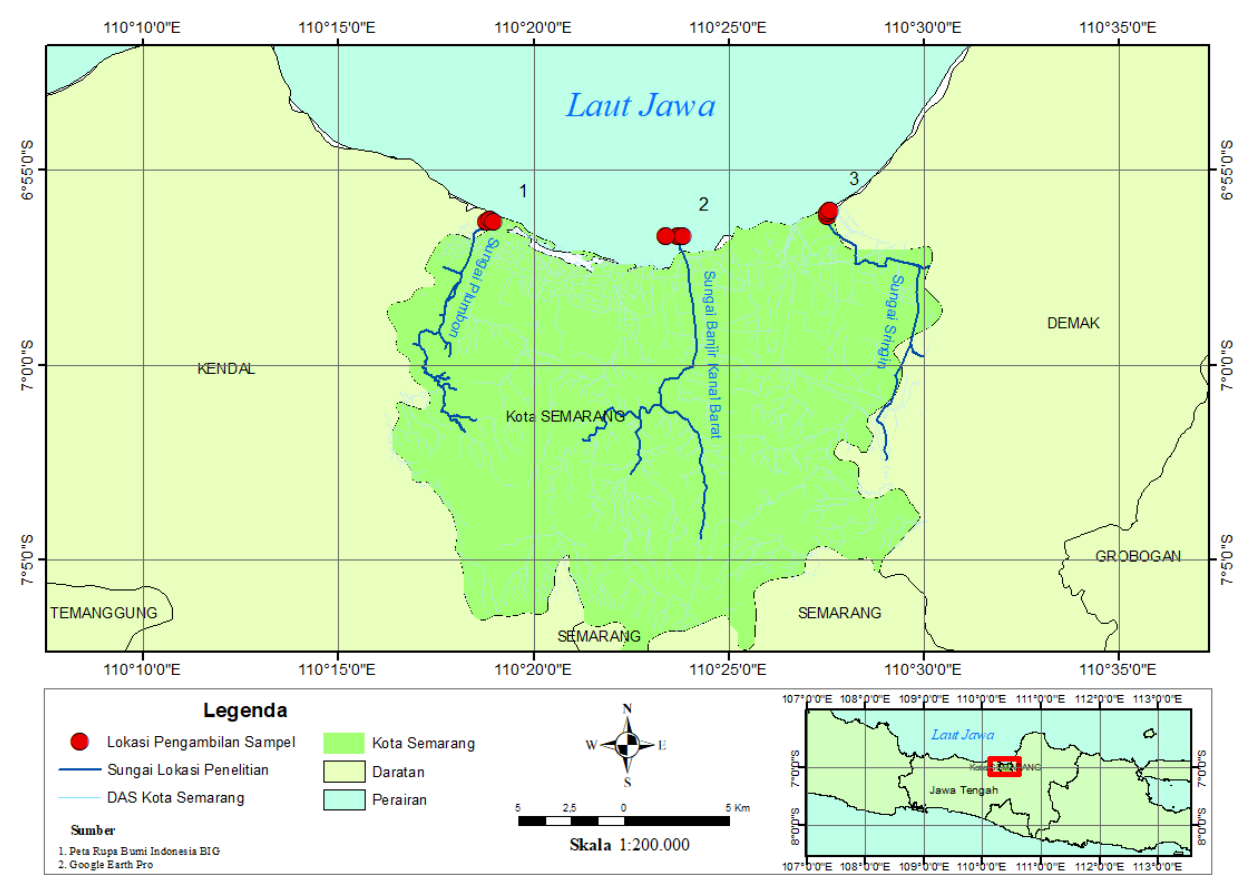

Gambar 1. Lokasi pengambilan sampel sedimen di muara Sungai Plumbon, Banjir Kanal Barat dan Sringin Kota Semarang

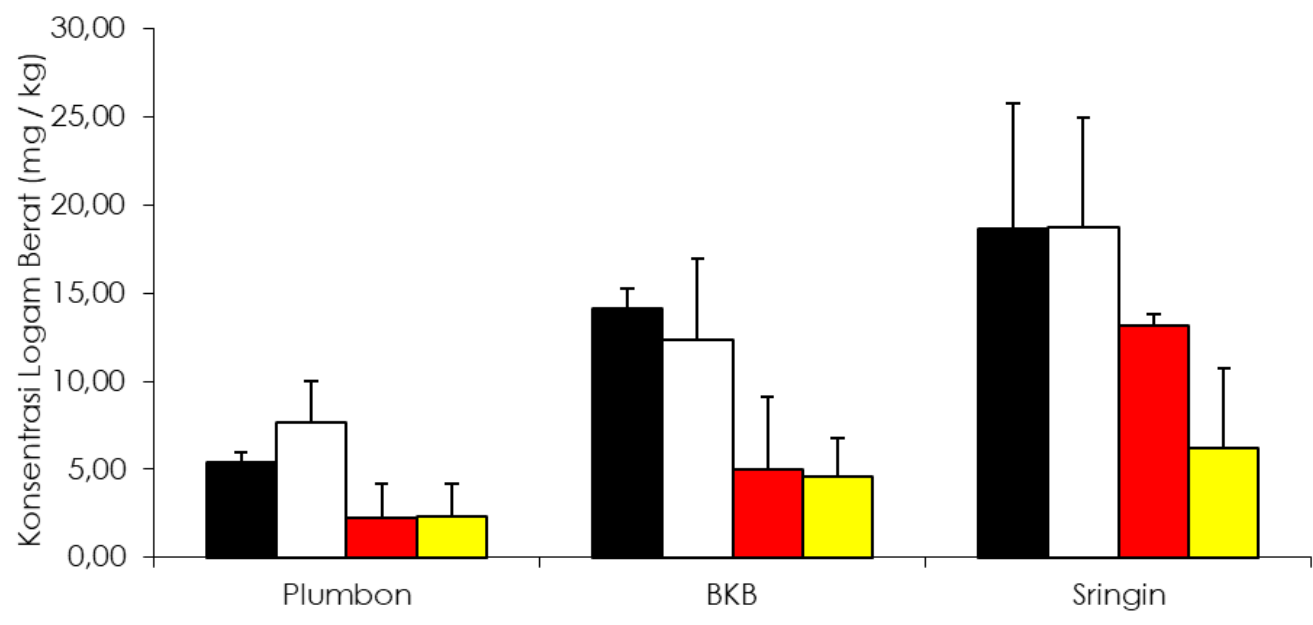

Lokasi Muara Sungai

- Pb Permukaan aPb Dasar aCuPermukaan aCu Dasar

Gambar 2. Konsentrasi logam Pb dan Cu pada sedimen permukaan dan dasar di muara Sungai Plumbon, Banjir Kanal Barat dan Sringin Kota Semarang. 




Gambar 3. Prosen Total organik karbon (TOC) dan prosen silt + clay pada sedimen permukaan dan dasar di muara Sungai Plumbon, Banjir Kanal Barat dan Sringin Kota Semarang.


Gambar 4. Matrik hubungan logam berat $\mathrm{Pb}$ permukaan, $\mathrm{Cu}$ permukaan sedimen terhadap porsentase total organik karbon dan porsentase kandungan (silt + clay) permukaan dan hubungan $\mathrm{Pb}$ dasar, $\mathrm{Cu}$ dasar sedimen terhadap porsentase total organik karbon dan porsentase kandungan (silt + clay) dasar.

tersebut dalam sedimen dsangat tergantung masukan dari aktifitas manusia. Hal tersebut juga terjadi di Dagu Estuaria China yang menunjukan tidak adanya sebaran yang linier berdasarkan kedalaman (LÜ et al., 2007). Demikian pula informasi dari Daessle et al. (2009) yang mengambil sampel di Delta Colorado yang mengatakan distribusi konsentrasi logam berat tidak menunjukan peningkatan maupun penurunan berdasarkan kedalaman sedimen. Hal yang sama juga terlihat di pesisir laut Merah Arab
Saudi dimana logam berat seperti $\mathrm{Cd}, \mathrm{Pb}, \mathrm{Ni}$, $\mathrm{Cu}, \mathrm{Zn}, \mathrm{Cr}$ dan $\mathrm{Mn}$ juga menunjukan kecenderungan yang tidak teratur peningkatan maupun penurunya berdasarkan kedalaman sedimen (Badr et al., 2009).

Gambar 3 menunjukan prosentase bahan organik yang terdapat dalam sedimen dasar lebih tinggi bila dibandingkan dengan yang terdapat pada sedimen permukaan pada tiga muara sungai, dengan 
perbedaan yang sangat nyata $(p<0,01)$. Namun prosentase kandungan silt dan clay (lanau dan lempung) pada sedimen permukaan dan dasar di tiga muara sungai menunjukan tidak adanya perbedaan $(0,05 \leq p)$.

Hasil analisa matrik plot pada gambar 4 menunjukan bahwa prosentase total organik karbon dan (silt + clay) pada permukaan sedimen bila secara bersaman tidak memberikan pengaruh pada tinggi rendahnya konsentrasi $\mathrm{Pb}$ pada permukaan sedimen $(r=0.095 ; p=0,74>0.05)$ dengan regresi $Y=4.07+0.79 \mathrm{X}_{1}-0.25 \mathrm{X}_{2}$. Demikian juda terhadap Cu permukaan $(r=0.29 ; p=$ $0,49>0.05)$ dengan regresi $Y=5,54+1,64 X_{1}+$ $1,03 X_{2}$. Demilian juga pada prosentase total organik karbon dan (silt + clay) dasar sedimen bila bersamaan tidak memberikan pengaruh pada tinggi rendahnya konsentrasi $\mathrm{Pb}$ dan $\mathrm{Cu}$ pada dasar sedimen. Untuk $\mathrm{Pb}$ dasar sedimen $(r=0.21 ; p=0.49>0.05)$ dengan regresi $Y=3,06+0,24 X_{1}-0,54 X_{2}$. Sedangkan untuk $C u$ dasar $(r=0.24 ; p=0,44>$ $0.05)$ dengan regresi $Y=10,2+0,67 X_{1}-0,47 X_{2}$. Dari penjelasan tersebut dapat dikatakan bahwa akumulasi logam berat $\mathrm{Pb}$ dan $\mathrm{Cu}$ dalam sedimen permukaan maupun dasar yang diambil di tiga muara Sungai Plumbon, Banjirkanal Barat dan Sringin tidak tergantung dari banyak sedikitnya prosentase total organik karbon dan gabungan dari silt dan clay. Hal tersebut berbanding terbalik dengan penelitian Galanopoulou et al. (2009) yang melakukan penelitian di pelabuhan Keratsini dan teluk Saronikos Yunani logam berat antropogenik seperti Cd, $\mathrm{Pb}, \mathrm{Zn}, \mathrm{Mn}, \mathrm{As}, \mathrm{Se}, \mathrm{Cr}, \mathrm{Cu}$ keberadaanya dalam sedimen bagian atas berbanding lurus dengan bahan organik karbon. Daessle et al. (2009) menginformasikan peningkatan logam antropogenik dalam sedimen bagian permukaan dan bawah tergantung dari masukan oleh aktivitas dan adanya perubahan sepanjang Delta Corolado.

Penelitan logam berat pada lapisan lapisan sedimen dapat dijadikan data tentang pengaruh ekositem perairan karena faktor alam dan masukan oleh manusia pada peride waktu (Buckley et al. 1995). Sebenarnya keberadaan logam berat antropogenik dalam sedimen di lingkungan perairan seperti pesisir atau estuaria sangat membahayakan bagi kehidupan organisme benthik. Organisem benthik seperti kerang yang memiliki kemampuan bioakumulasi sangat mudah mengakululasi logam berat dan tahan terhadap polutan tersebut (Won et al., 2016). Hal tersebut juga terlihat di perairan Brebes dimana konsentrasi logam berat danal kerang Anadara lebih tinggi terhadap logam beerat dalam air laut dan sedimen (Suryono et al., 2018). Logam berat pada umumnya lebih cenderung menjadi lebih beracun dan berpotensi penyebab kontaminasi karena bersifat stabil dan tidak terurai dalam lingkungan perairan, jadi mudah terakumulasi dalam biota dan biomagnifikasi dalam rantai makanan (Valdes et al., 2014)

\section{KESIMPULAN}

Tinggi rendahnya logam berat antropogenik $\mathrm{Pb}$ dan $\mathrm{Cu}$ pada lapisan bagian atas dan bawah sedimen yang diambil di tiga muara sungai (Plumbon, Banjir Kanal Barat dan Sringin) tidak ada hubungannya dengan jumlah total bahan organik karbon maupun dengan gabungan antara silt dan clay dalam sedimen. Namun di ketiga muara sungai tersebut konsentrasi $\mathrm{Pb}$ baik pada permukaan maupun bawah sedimen lebih tinggi dari pada konsentrasi Cu baik pada permukaan maupun bawah sedimen.

\section{DAFTAR PUSTAKA}

Badr, N.B.E., El-Fiky, A.A., Mostafa, A.R \& AlMur, B.A., 2009. Metal pollution records in core sediments of some Red Sea coastal areas, Kingdom of Saudi Arabia. Environ Monit Assess 155:509-526 doi: 10.1007/s 10 661-008-0452-x

Buckley, D.E., Smith, J.N., \& Winters, G.V., 1995. Accumulation of contaminant metals in marine sediments of Halifax Harbour, Nova Scotia: Environmental factors and historical trends. App. Geochem. 10(2):175-195. doi: 10.1016/08 83-2927(94)00053-9.

Daessle, L.W., Ibarra, K.C.L., Tobschall, H.J., Melo, M., Galindo, E,A,G., Hernandez, J.G., \& Alvarez, L.G., 2009. Accumulation of $\mathrm{As}, \mathrm{Pb}$, and $\mathrm{Cu}$ Associated with the Recent Sedimentary Processes in the 
Colorado Delta, South of the United States-Mexico Boundary. Arch. Environ. Contam. Toxicol. 56:680-692 doi: 10.1007/ s00244-008-9218-2

Daessle, L.W., Ramos, S.E., Carriquiry, J.D., \& Camacho, V.F., 2002., Clay dispersal and the geochemistry of manganese in the Northern Gulf of California. Cont. Shelf. Res. 22:1311-1323. doi:10.1016/S0278-4343 (02)00007-9)

Froehner, S. \& Martins, R. F., 2008., Evaluation of the chemical composition of sediments from the Barigüi river in Curitiba, Brazil. Quim. Nova. 31 (8):20202026

Galanopoulou, S., Vgenopoulos, A., \& Conispoliatis, N. 2009. Anthropogenic Heavy Metal Pollution in the Surficial Sediments of the Keratsini Harbor, Saronikos Gulf, Greece. Water Air Soil Pollut. 202:121-130 doi: 10.1007/s11270-00 8-9962-y

Hunter, K.A., 1983., On the estuarine mixing of dissolved substances in relation to colloid stability and surface properties. Geochim Cosmochim Acta 47:467-473. doi: 10.101 6/0016-7037(83) 90269-7

Liu, J.H., Cao, L., Huang, W., \& Dou, S.Z., 2013. Species- and tissue-specific mercury bioaccumulation in five fish species from Laizhou Bay in the Bohai Sea of China. Chin. J. Oceanol. Limnol. 31:504-513

LU, J.X., Wang, Y.W., Zhang, Q.H., Gao, E.L \& Jiang, G.B., 2007., Contamination trends of polybrominated diphenyl ethers, organochlorine pesticides and heavy metals in sediments from Dagu Drainage River estuary, Tianjin, Chinese Science Bulletin 52(10):1320-1326

Mariani, C.F., \& Pompeo, M.L.M., 2008., Potentially bioavailable metals in sediment from a tropical polymictic environment-Rio Grande Reservoir, Brazil. J. Soils Sediments, 8(5):284- 288.

Metcalf \& Eddy, 1991., Wastewater engineering treatment, disposal and reuse. McGraw Hill, inc. New York. 1334 p

Rutemberg, K.C., \& Goni, M.A., 1997., Phosphorus distribuition, $\mathrm{C}: \mathrm{N}: \mathrm{P}$ ratios, and
$813 \mathrm{COC}$ in artic, temperate, and tropical coastal sediments: Tools for characterizing bilk sedimentary organic matter. Mar. Geo. 139(1):123-145

Strauch, G., Möder, M., Wennrich, R., Osenbrück, K., Gläser, H. R., \& Schladitz, T., 2008., Indicators for assessing anthropogenic impact on urban surface and groundwater. J. Soils Sediments, $8(1): 23-33$

Suryono, C.A., Widada, S., Rochaddi, B., Subagiyo., Setyati, W., \& Susilo, E.S., 2018., Kontaminasi logam berat Arsen, Mercury dan Magnesium pada air laut, sedimen dan Anadara inaequivalvis (Mollusca: Bivalvia, Bruguiera, 1792) di Perairan Brebes Indonesia. J.I Kelautan Tropis 21 (2): 150-154

Suryono, C.A., 2016., Akumulasi logam berat $\mathrm{Cr}, \mathrm{Pb}$ dan $\mathrm{Cu}$ dalam sedimen dan hubunannya dengan organisme dasar di perairan Tugu Semarang. Jurnal Kelautan Tropis 19 (2): $143-149$

Suryono, C.A., \& Djunaedi, A., 2017., Logam berat $\mathrm{Pb}, \mathrm{Cr}$ dan $\mathrm{Cd}$ dalam perairan pelabuhan Tanjung Mas Semarang. J. Kel. Trop. 20(1):25-29

Velez, C., Figueira, E., Soares, A., \& Freitas, R., 2015. Spatial distribution and bioaccumulation patterns in three clam populations from a low contaminated ecosystem. Estuar. Coast. Shelf Sci. 155:114-125

Viguri, J., Verde, J., \& Irabien, A., 2002., Environmental assessment of polycyclic aromatic hydrocarbons (PAH) in surface sediments of the Santander Bay, Northern Spain. Chemosphere, 48:157-165.

Won, E.J., Kim, K.T., Choi, J.Y., Kim, E.S., \& Ra, K., 2016. Target organs of the Manila clam Ruditapes philippinarum for studying metal accumulation and biomarkers in pollution monitoring: laboratory and in-situ transplantation experiments. Environ. Monit. Assess. 188(10):478 